\title{
The celebrity of anonymity and the anonymity of celebrity: picture identification and nineteenth-century British authorship
}

\author{
Kamilla Elliott, Lancaster University
}

Post-referee, pre-proofs version. 18 month embargo by Taylor \& Francis

\begin{abstract}
This article examines how the spaces between the words and images of various forms of picture identification (portraits, cartes de vistes, and early cinema) navigated the space between anonymity and identification to construct British writers as celebrities during the long nineteenth century. Literary authors in that period did not become celebrities by words alone, but through intersemiotic relations between words and images. These relations varied across technologies and ideologies, sometimes collaborating, sometimes vying for dominance, sometimes contradicting each other. These relations complicate and challenge late twentieth-century theories of authorship as well as illuminating nineteenth-century dynamics.
\end{abstract}

Keywords: authorship; celebrity; picture identification; intersemiotic relations; portraiture; early cinema

\begin{abstract}
A dextrous half concealment of oneself-or even an entire mystery, so as to cause a universal inquest, as to 'who is he I wonder?' has been no idle charlanterie: and has been, more than almost anything else, ancillary to publication. Hence half the fame of Junius and three-fourths of that of Walter Scott.—Don Roll. De L. S. de la Manch, 1832
\end{abstract}

Joseph A. Boone and Nancy J. Vickers consider that 'the middle ground is essential to anyone attempting to understand the breadth, depth, and intensity of the exchanges between $[\ldots]$ producers and consumers' of celebrity, as are middle grounds between 'modes of oral communication between performer and audience [...] the copying and circulation of manuscripts, the invention of print $[\ldots]$ and the creation of electronic 
media' (Boone and Vickers 2011, pp. 905-906). This article treats two interrelated middle grounds, tracing how the spaces between the words and images of portraits navigated the space between anonymity and identification to construct British writers as celebrities during the long? nineteenth century.

Richard Schickel has controversially claimed that 'there was no such thing as celebrity prior to the beginning of the twentieth century'; before that, he argues, there was only fame (1985, p. 21). The Victorians, however, did distinguish between celebrity and fame, deeming the former a more trivial affair, as Schickel and others have done. In 1863, for example, Matthew Arnold assessed that Spinoza's successors 'had celebrity[;] Spinoza had fame' (1863, p. 255). Spinoza's celebrity endured and became fame, while his imitators had only the temporary popular flutter of his reflected image. Celebrity belongs to the present; only longevity stretching into the future can confirm fame.

As in the twentieth century, nineteenth-century celebrity was embedded in pictorial images - but so too was fame. The public wanted to identify the famous and celebrated by pictures as well as words. In his preface to Portraits of Illustrious Personages of Great Britain, Edmund Lodge attests: 'As in contemplating the portrait of an eminent person we long to be instructed in his history, so in reading of his actions we are anxious to behold his countenance' (Lodge 1814, p. 2). Picture identification then and now consists of a combination of words and images. While today picture identification most commonly takes the abbreviated forms of passports, identity cards, and driving licenses, in the nineteenth century, named portraits were often starting points for more extensive identificatory processes, in which proper names spun into bulky biographies and faces into full-length bodies, as in Lodge's volumes. 
Today many critics worry about a 'cultural shift towards a culture that privileges the momentary, the visual and the sensational over the enduring, the written, and the rational' (Turner 2004, p. 4); in the nineteenth century, the focus was on tensions, rivalries, and collaborations between written and pictorial aspects of picture identification. The words and images of picture identification engage in reciprocal referentiality: the name identifies the image; the image identifies the name. Picture identification indicates a further reciprocity between pictures and persons: pictures identify persons, but persons also identify pictures. In the long nineteenth century, named pictures generated aesthetic, moral, and biographical discourses that further identified cultural ideologies and values. Debates over whether words or images are truer indicators of identity were particularly fraught in discourses of celebrity authors, whose celebrity initially was predicated on their production of words. At times, their images seemed to cement and confirm that celebrity; at others, they appeared to undermine it, as I detail below.

Picture identification took various forms from engraved frontispieces to photographic cartes de visite to early motion pictures. Portrait frontispieces were often used to announce the identities of hitherto anonymous or pseudonymous authors within their works. By contrast, cartes de visite often identified authors apart from their proper names and writings. While some authors argued for the superior powers of images over words to represent their identities, others withheld their images from publication, forging a pictorial anonymity in order to be identified solely by their names and writings, as I demonstrate below. At the turn of the twentieth century, anonymous actors portrayed dead celebrity authors in motion pictures. These incursions of the theatrical into photographic realism and interchanges of moving images with filmed still portraits destabilized and fragmented older word-image 
relations, such as named painted or engraved portraits. Consumers began to clamour for the names of anonymous actors such as 'The Biograph Girl', Florence Lawrence, who became a named attraction from 1910, when she moved to the Independent Motion Picture Company. Increasingly, celebrity authors were displaced by celebrity actors in motion pictures.

Joining changing technologies, cultural ideologies created further variations in the picture identification of authors. In the first half of the century, picture identified authors were expected to manifest other values besides literary merit, depending on their class and gender. Bourgeois authors were invariably required to manifest moral character; those of noble birth could dispense with it and still be celebrities. For bourgeois women, the moral content of their writings often weighed more heavily than their literary merit; with the advent of photographic portraiture, popular hunger for female beauty placed new pressures on the picture identification of women writers, although as I argue below, photographs, like drawn and painted portraits, could be and were retouched. The point to glean from these and other expectations is that literary celebrity did not live by literature alone, but by images and other indices of cultural value, which literary celebrity was expected to confirm.

\section{Literary Authors and National Print Galleries}

No biography is complete without a portrait.—'The Vanity Fair Album' (1873:

The People's Art Union's ' Historic Gallery of Portraits assesses that 'The union of History, Painting and Sculpture, and their dependence upon each other is so apparent as to render unnecessary any further observation' (Anon 1845, p. v). Yet in any 
academic study, further observations are generally made. Prior to the print technologies that made illustrated literature increasingly affordable, portraits were held in private collections, only occasionally exhibited to the public. The preface to the Biographical History of England, celebrates engraving's dissemination of portraiture: "no invention has better answered the end of perpetuating the memory of illustrious men than the modern art of engraving' (Granger 1769, p. xiv). This eighteenth-century illustrated portrait gallery privileges royals, aristocrats, and the dead: those whose past celebrity has become present fame. In the nineteenth century, however, William Jerdan's National Portrait Gallery (1830-34) celebrates presentday celebrities, seeking to cement their current celebrity as future fame by fixing their picture identification in print:

it is the grand object of the National Portrait Gallery to preserve and transmit to posterity the features and the memory of those who have earned greatness in the present age in all the paths that lead to distinction or to glory $[\ldots]$ their plan embraces beauty, illustrious birth, the church, the law, the army, the navy, the sciences, the fine arts, and the literary character. (Jerdan 1830, 1: pp. 7-8) ${ }^{2}$

Although Jerdan's criteria include 'illustrious birth', no one appears solely on that basis; all of his aristocrats must manifest professional achievement as well. Concomitantly, his first picture-identified authors, George Gordon, Lord Byron (volume 1) and Sir Walter Scott (volume 3), are of noble birth, bridging older and newer criteria for celebrity. His other literary authors-William Wordsworth, Hannah More, and Jane and Anna Porter - are middle class. All are celebrated for their moral character as well as literary merit: Wordsworth for his benevolence, beauty, universal sympathy, natural religion, and faith in universal moral harmony (Jerdan 1833, 4: p. 3). ${ }^{3}$ Moral character plays an even greater role in Jerdan's picture identification of female authors, outweighing their literary merit: while the gallery's men are the most 
celebrated authors of the day, the women are not. Anna Porter is implicitly set against more popular women authors such as Ann Radcliffe, hailed for 'the purity of her moral character, and the elevating religion of the soul ... the simplicity of her manners, the affability of her temper' (Jerdan 1834, 5: p. 7); Jane Porter is commended for 'grave deportment' (Jerdan 1834, 5: p. 8).

While Byron is admitted to the gallery, no morally dubious middle-class author of either gender is allowed. Even so, he is judged by bourgeois values for his 'wretched morality' (Jerdan 1830, 1: p. 4), while Scott is lauded for his rejection of aristocratic 'indifference' and 'selfishness' and for undertaking literary labour rather than living in entitled indolence (Jerdan 1832, 3: p. 1). In both its exclusions and inclusions, the gallery inscribes a closed circuit of cultural value in which celebrities are valued according to bourgeois ideologies and bourgeois ideologies are valorized by celebrities.

\section{Anonymous Authorship and Picture Identification}

A portrait will not tell you all you want to know about a man; but it throws important light upon his character, and supplies a clue to much that might otherwise be dark and hidden.- 'The Vanity Fair Album' (1873, p. 384)

For Michel Foucault some 150 years later, it is the proper name that allows authors to become subjects of discourses that celebrate them (Foucault 1984). However, the fact that nineteenth-century authors often published anonymously and that consumers were obsessed with seeing pictures of authors problematizes the applications of his theory to the period. In $1830,80 \%$ of novels were published anonymously or pseudonymously (Griffin 2006, p. 49). The proper name that constitutes the core of Foucault's theory was thus more often than not withheld, substituted, collapsed into 
initials, and displaced by common nouns (for example, 'by a lady'). The common noun 'author' was frequently identified by the proper names of book titles (for example, 'by the author of "Waverley"; 'by the author of "Sense \& Sensibility"), Some works were entirely unsigned by any of these substitute indicators (Griffin 2006, Eckroth 2012).

Another limitation of Foucault's theory for discussions of nineteenth-century literary celebrity is his distinction between the author function from the biographical connotations of an author's proper name: 'the author's name, unlike other proper names, does not pass from the interior of a discourse to the real and exterior individual who produced it' (Foucault 1984, p. 107). As with film stars of the twentieth century (De Cordova 1990, p. 98), the biographical lives of celebrity authors were a central public focus: 'we are no sooner interested by the writings of an author, than our curiosity is awakened for his history, his fortune, and his character' (Anon 1788, p. v). For many scholars, such interest is as essential to the definition of celebrity as the proper name (Ives 2012, p. 1).

More central to my focus in this essay, Foucault's emphasis on the proper name and verbal discourse obfuscates the centrality of visual representation to celebrity (Boone and Vickers 2011, p. 907). When nineteenth-century authors undertook the passage from anonymity to celebrity, whether by their own agency or that of others, during their lifetimes or after their deaths, they did not do so by proper names and words alone, nor merely by words and images working 'in tandem' (Ives 2012, p. 4); they did so by forging intersemiotic ${ }^{1}$ exchanges of words and images within various forms of picture identification.

\footnotetext{
${ }^{1}$ Intersemiotic refers to a translation or exchange between two different types of media (Banting 1995, p. 11).
} 
Picture identification requires a proper name; the honorific picture identifications of print galleries therefore rested uneasily with conventions of anonymous authorship. All of the authors celebrated by Jerdan began their careers anonymously (Griffin 2006, pp. 49-50; Stott 2003, pp. 63 and 97; Greenfield 1996, p. 268). Discussing the failure of John Keats and Thomas Chatterton to attain celebrity in their lifetimes, Leo Braudy considers that: 'In the late eighteenth and early nineteenth century an increasingly fame-choked world was beginning to reach out for solace and value to anonymity and neglect as emblems of true worth' (Braudy 1986, p. 425). However, the etymologies of anonymity ('without a name') and celebrity ('drawing a crowd') indicate that the two words are not antonyms; nor are celebrity and fame: rather, celebrity is implicated in the etymology of fame ("celebrated in fame'), while nameless authors became objects of discourse without proper names, and were celebrated in the sense of 'much talked about' $(O E D)$.

Griffin identifies pragmatic reasons for anonymous publication in the period: 'modesty, anxiety over reception, and fear of prosecution [...] to explore assumed identities, to escape a prejudged reception based on one's previous work, or to trick one's critics' (Griffin 2006, pp. 48 and 50). Nineteenth-century critics were every bit as savvy as twentieth-century scholars, understanding that authors published anonymously as a 'gimmick to attract attention and sustain sales' (Hayden 1970, p. 4). Stephanie Eckroth's statistical study of the Romantic literary marketplace challenges prior feminist explanations for female anonymity, demonstrating that men were as likely to hide their names as women (some even used female pseudonyms), and that successful female novelists who revealed their proper names following anonymous beginnings garnered the highest book prices (Eckroth 2012, pp. 20 and 26-28). Anonymity, then, fuelled and enhanced celebrity in various ways. 
Although Foucault considers that an author's proper name is required for her to become a function of discourse, the absence of authorial proper names ushered in a host of celebratory discourses, arguably more than the proper name alone. Scott, for example was nominated 'The Great Unknown', along with a panoply of other celebratory adjectives and common nouns (Hayden 1970, p. 4), laying a verbal red carpet along which he could reveal his proper name at the Annual Theatrical Edinburgh Fund Dinner in February 1827 (Anon 1827, p. 154).

The nineteenth-century passage from anonymity to celebrity further problematizes Roland Barthes's poststructuralist theory of 'the death of the author'. Barthes's resounding poststructuralist obituary for Romantic theories of transcendent, original, individual, expressive authorship reconfigures relations among authors, texts, and readers:

$[W]$ riting is the destruction of every voice, of every point of origin ... the voice loses its origin, the author enters into his own death, [when] writing begins ... [There is] no other origin than language itself, language which ceaselessly calls into question all origins ... it is language which speaks, not the author ... [A] text is not a line of words releasing a single 'theological' meaning (the 'message' of the Author-God) but a multidimensional space in which a variety of writings, none of them original, blend and clash ... a text is made of multiple writings, drawn from many cultures and entering into mutual relations of dialogue, parody, contestation, but there is one place where this multiplicity is focused and that place is the reader, not ... the author. (Barthes 1977, pp. 142, 143, $146,148)$ 
Although Scott announced his identity in a speech at the dinner, it was widely canvassed prior to that in various oral and printed discourses; following his announcement, he maintained anonymity within the pages of his published works; only after his death did his proper name appear on them, as on a tombstone. In an anachronistic parody and literalization of Barthes's theory, the biological death of the biographical author allows the proper name to be printed.

Scott's death further allowed him to be picture identified as the author of his books within and apart from their pages, as engraved portraits were purchased in the thousands. These worked less to satisfy a quest for his name than to identify his personality. When in 1834 Charles Tilt printed and sold 14,000 mezzotint engravings of Charles Robert Leslie's portrait of Scott, an Atlas reviewer read the image to identify Scott's character through his physiognomy:

We have never seen a greater power of expression than is lodged in the eyes of this portrait ... the benevolence that breathes between the lips, impressed indeed with the energy of thought, but mild in their firmness [...] all as vivid and as faithful as in the picture itself and that is all but reality. (Anon 1834, p. 307)

The images of portraits, then, opened spaces for authorial identity to be written by others beyond the proper name and public actions and for these identifications to be identified with 'reality'.

Named portraits were also spaces in which to contest the relative identificatory authority of words and images. Both writing and portraits were deemed to manifest soul, psyche, and character (ref). Romantic theories of expressive authorship viewed writing as the expression of the author's biographical life: 'The life of Wordsworth is 
in his works, and the biographer can do little more than give the outline of a career, to be filled up from his own pages' (Jerdan 1833, 4: p. 3). Chorley similarly conflates the biographical and authorial identities of Felicia Hemans: 'the woman and the poetess being one' (Chorley 1828, p. 5). Today, in spite of theoretical refutations of expressive authorship, scholars still write of 'reading Scott' and other authors, conflating authorial names with the names of their works (Elliott, 2012a, p. 179).

Such conventions were fuelled by anonymous publication: we have seen that, in the absence of a proper name, authors were often identified by the proper names of their novels. When novels were titled with the names of their protagonists, authors were further nominally identified and often conflated with principal characters. Such associations were intensified in novels purporting to be written by their protagonists. In 1839, Charles Dickens used picture identification not only to assert his authorship over his illustrators (Cohen 1980) and the playwrights who adapted his fiction (Gould 2011, p. 130), but also to set his biographical authorial identity against the authorial claims of his characters. Until its last instalment, Nicholas Nickleby was credited as 'edited by Boz', Dickens's pseudonym, and authored by its eponymous protagonist. The frontispiece illustrations to earlier instalments, following literary conventions, represented Nicholas. However, the frontispiece of the final instalment displaced Nicholas with a portrait of Dickens engraved from a painting by Daniel Maclise. It further displaced the usual printed caption bearing the protagonist's name with a facsimile of Dickens’s signature, 'Faithfully yours, Charles Dickens' (Patten 2001, pp. 16-33). In the book that followed the serialization, the authorial portrait and handwritten signature lie on the left page facing a printed title page that confirms that the novel's author is Charles Dickens. 
This picture identification did more than reveal this author's proper name; it was also deemed to reveal his character. Today, biographers still read the characters of authors through their fiction, while handwriting, especially autographs, still serves as proof of legal identity. Many nineteenth-century critics believed that

a man's character is manifested in his writing. The penmanship of one individual differs widely from that of another individual [...] When a man signs his name, he does something which, so to speak, brings out himself; and he generally throws into his signature a decisiveness which in the rest of his writing you may vainly look for. (Anon 1858, p. 11)

The epigraph to this section indicates that portraits too were seen to indicate character. Writing and portraiture, however, were not seen to represent character in the same ways. Rather, they were perceived to engage in a reciprocal, inverse relationship: Romantic theories of writing emphasised expressivity; neoclassical theories of portraiture foregrounded immanence; expressivity moves from the inner to the outer; immanence moves through the outer to the inner (Elliott 2012b, pp. 28-29). Together, picture identification exposes and invades identity from the inside out and the outside in.

Authors therefore wrestled for control over their picture identification and wrangled over which aspects of picture identification would predominate in their identification. Writing foregrounds authorial agency; unless the author has drawn a self-portrait, portraiture emphasises the artistic agency of another, while its passive immanence prioritizes viewer penetration of and discourses upon the image.

Dickens's handwritten signature asserts the expressivity and individuality of the writing author against the impersonality and uniformity of print; although it too is mass-produced, 'the facsimile autograph created the illusion of cultlike aura in an age of mechanical reproduction' (Blake 2008, p. 42). It further asserts the self-identifying, 
expressive authorial body writing against the body painted and engraved by other hands and the words uttered by viewers upon that image. ${ }^{4}$

While Jane Austen's identity was not revealed in print until after her death, Charlotte Brontë cast off anonymity during her lifetime to identify herself as author of Jane Eyre when its authorship was conflated with that of her sisters. She seized on their deaths to write a biographical notice identifying them as dead authors and herself as a living author. She equally bristled at being identified with her fictional protagonist. When her literary idol, William Makepeace Thackeray, introduced her as Jane Eyre, she protested vehemently, insisting that she would never introduce Thackeray as one of his characters (Smith 1900, pp. 790-791).

Dickens and Brontë were not alone in shaking off anonymity to differentiate their identities from other authors and their own characters. George Eliot revealed her identity when another author claimed to have written Adam Bede. But George Eliot was not her biographical name. Kyriaki Hadjiafxendi considers that Mary Ann Evans hid behind the male pseudonym George Eliot 'in order to empty out her name from her personality and separate her life from her work' (Hadjiafxendi 2013, p. 189). Patricia Zakreski extends the idea beyond Eliot and the female gender:

The belief in literature as a revelation of personality was repeatedly denied by writers throughout the second half of the nineteenth century not only because it destabilised private respectability; it also undermined the perception of literature as a professional occupation for both men and women. (Zakreski 2006, p. 138)

Yet intriguingly, while Brontë would not identify Thackeray with his characters, she readily identified him with his portrait: 'At a late hour yesterday 
evening I had the honour of receiving, at Haworth Parsonage, a distinguished guest, none other than W. W. Thackeray, Esq.' The letter describes the arrival of his portrait, which she continues to mockingly conflate with his person:

Mindful of the rites of hospitality, I hung him up in state this morning. He looks superb in his beautiful tasteful gilded gibbet. For companion he has the Duke of Wellington ... and for contrast and foil Richmond's portrait of an unworthy individual, who, in such society, must be nameless [Charlotte Brontë]. Thackeray looks away from the latter character with a grand scorn, edifying to witness. (Brontë 2004, p. 128)

Tellingly, while she makes no rhetorical distinction between Thackeray and Wellington and their portraits, she differentiates herself from her own portrait, nominating it a 'character'. The distinction suggests that she denies identity to others' identification of her; by contrast, her letter makes no distinction between her verbally represented self, the 'I' of the letter, or her signature at its end. She is thus willing to equate her identity with her autobiographical writing.

Beyond her conflation of Thackeray with his portrait, Brontë's possession and reading of it grant her authority to identify and judge him as a character and to do so in writing:

To me the broad brow seems to express intellect. Certain lines about the nose and cheek betray the satirist and cynic; the mouth indicates a childlike simplicity—perhaps even a degree of irresoluteness, inconsistency—weakness in short, but a weakness not unamiable. (Brontë 2004, p. 128) 
Following her conflation of the man and portrait, she engages physiognomy to read the portrait as moralist and art critic, differentiating Thackeray the man from his portrait:

The engraving seems to me very good. A certain not quite Christian expression $[\ldots]$ an expression of spite, most vividly marked in the original, is here softened, and perhaps a little — a very little — of the power has escaped in this ameliorating process. (Brontë 2004, p. 128, original emphasis)

Paradoxically, while engraving allows the wider dissemination and discursive judgment of celebrity portraits, its artifactuality mitigates that judgment by softening the irreligious expression of spite in the painting that it copies. Yet Brontë proclaims herself undeceived and 'hangs' Thackeray all the same. Here and elsewhere, discourses on picture identification from the 1790s on granted unprecedented discursive authority to women over those considered to be their social superiors (Elliott 2012b, pp. 171-185). In this case, a nameless, fledgling woman author judges and gibbets a male literary lion.

Brontë's own 'nameless' portrait, unlike Thackeray's, was not mass-produced and circulated until after her death in Gaskell's biography (1857), both supporting feminist claims about the immorality of circulating images of early Victorian women during their lifetimes (e.g., Smith 1999, pp. 93-94) and protecting Brontë from similar character judgments. However, the popularity of women authors in engraved print galleries and the fact that moral critiques extended to male as well as female picture identification (Fern 1862) moderates feminist claims. 
Aesthetic as well as moral conventions restricted the picture identification of women authors early and mid-century. Both Jane Austen's brother and Charlotte Brontë refused to send portraits of their dead siblings to accompany their biographical notices, probably because they were amateur productions by family members. By contrast, when Charlotte died, her portrait by George Richmond fulfilled aesthetic conventions (see the bibliography for a link to the portrait). Eventually, in the absence of any professional portrait, Cassandra Austen's sketch of Jane (Figure 3) was altered by watercolourist James Andrew before engraving by William Home Lizars (Figure 4) for her nephew's memoir in 1870 (Kirkham 2005).

As female authorial names were not always accompanied by portraits, so too, portraits of female authors did not always bear their proper names. When Samuel Laurence's portrait of George Eliot was exhibited at the Royal Academy in 1867, it was identified only as "The author of "Adam Bede"' (Anon 1881, p. 47). While critics have explicated this in terms of Eliot's sexual impropriety and mid-century prudery, that the highly moral Elizabeth Gaskell was also unnamed decades later in a posthumous portrait suggests that other dynamics were operative. Writing of Gaskell's bust erected at Knutsford post office in 1898, a critic considers that "Sufficient indication is given of the name in the fact that a copy of "Cranford" lies at the base of the figure, together with a quill pan and a laurel wreath' (Payne 1900, p. 120). Here it seems that while the sculpted image is no longer deemed immodest, to name it with her proper name goes one step too far. The portrait undoes Gaskell's declaration of her authorial name forty-one years earlier on the title page of Charlotte's biography, where she too used the death of a 'sister' author to identify herself not only as the author of the biography, but also of her hitherto anonymously published novels, doing so more definitively than Brontë, who retained her 
pseudonym in print. The bust re-anonymizes Gaskell's authorship even as it claims to celebrate it, displacing her biographical name with the title of her most celebrated work and pictorial symbols of authorship.

If picture identification was often lacking for women authors, women authors were equally often considered lacking for picture identification. The primary claims to picture identification for females had for centuries been rank and beauty; the beautiful Countess Blessington met these criteria and her portraits were exhibited, engraved, and widely circulated unproblematically much earlier in the century (Hawkins 2012). By contrast, she was deemed lacking in literary merit: Chorley critiques Blessington for 'display[ing] little — too little, perhaps — of the authoress' in her writings (Chorley 1828, p. 36, original emphasis). Richmond's portrait of Charlotte Brontë and Laurence's of Eliot were, by all contemporary accounts, highly flattering. The reproduction of Laurence's portrait (see Figure 1), together with a carte de visite photograph of Eliot on the National Portrait Gallery website (see Figure 2), allows viewers to make a comparison. Similarly, Austen's portrait by Cassandra (Figure 3), was not only clothed and coiffed by Andrew to suit Victorian tastes (Figure 4), her sharp, satiric, squinting, intellectual face was redrawn to meet standards of female beauty and moral character (Kirkham 2005, pp. 70 and 77). The partiality (in both senses of the word) of such picture identifications resulted in layers of pictorial anonymity and pseudonymity being retained or reinscribed. 


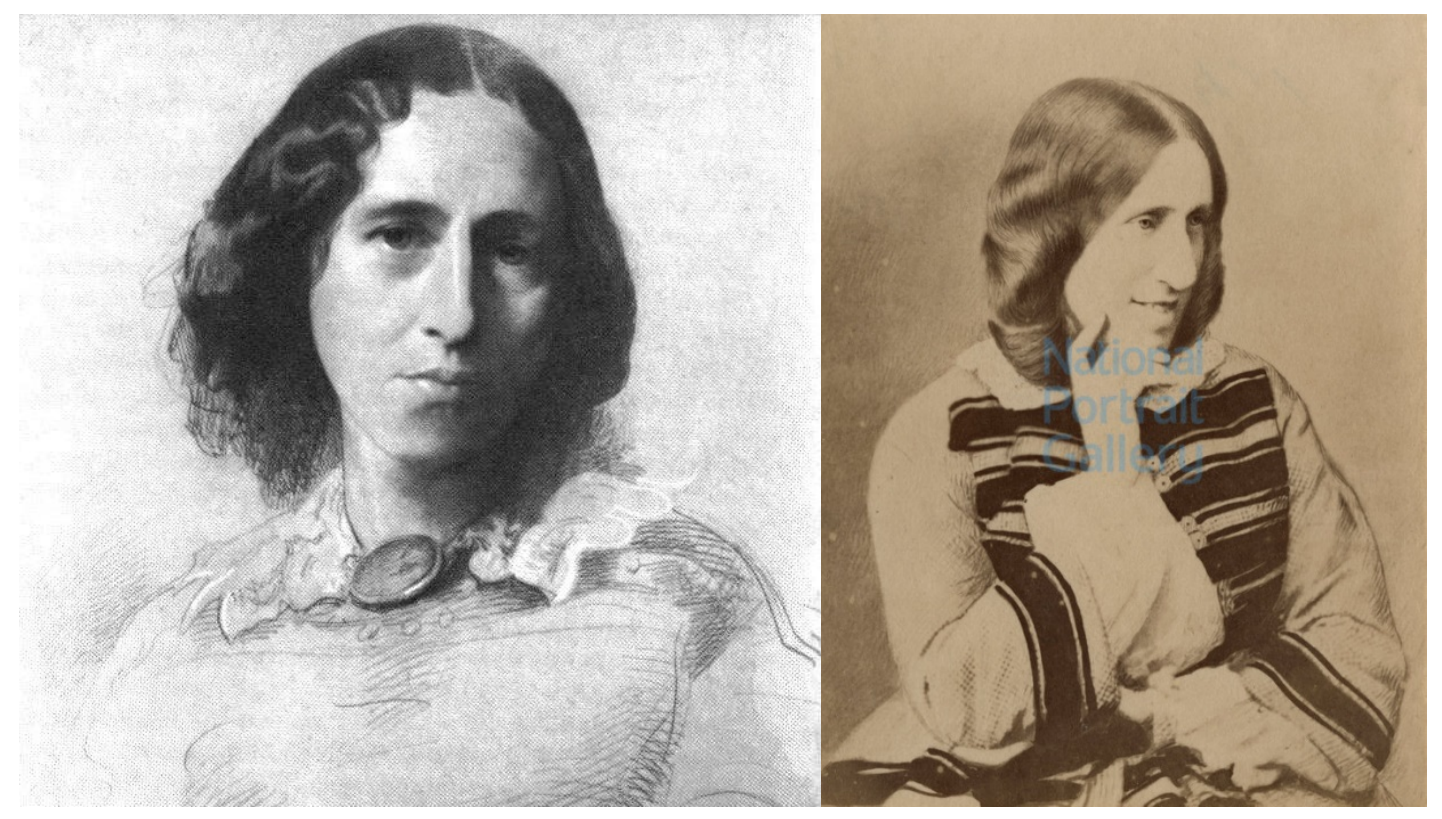

Fig. 1 Samuel Laurence's portrait of George \& Photographic Company (C) National Portrait Eliot [Public domain], via Wikimedia Gallery, London

\section{Commons}

Fig. 2 George Eliot (Mary Ann Cross (née

Evans)), carte de visite, London Stereoscopic

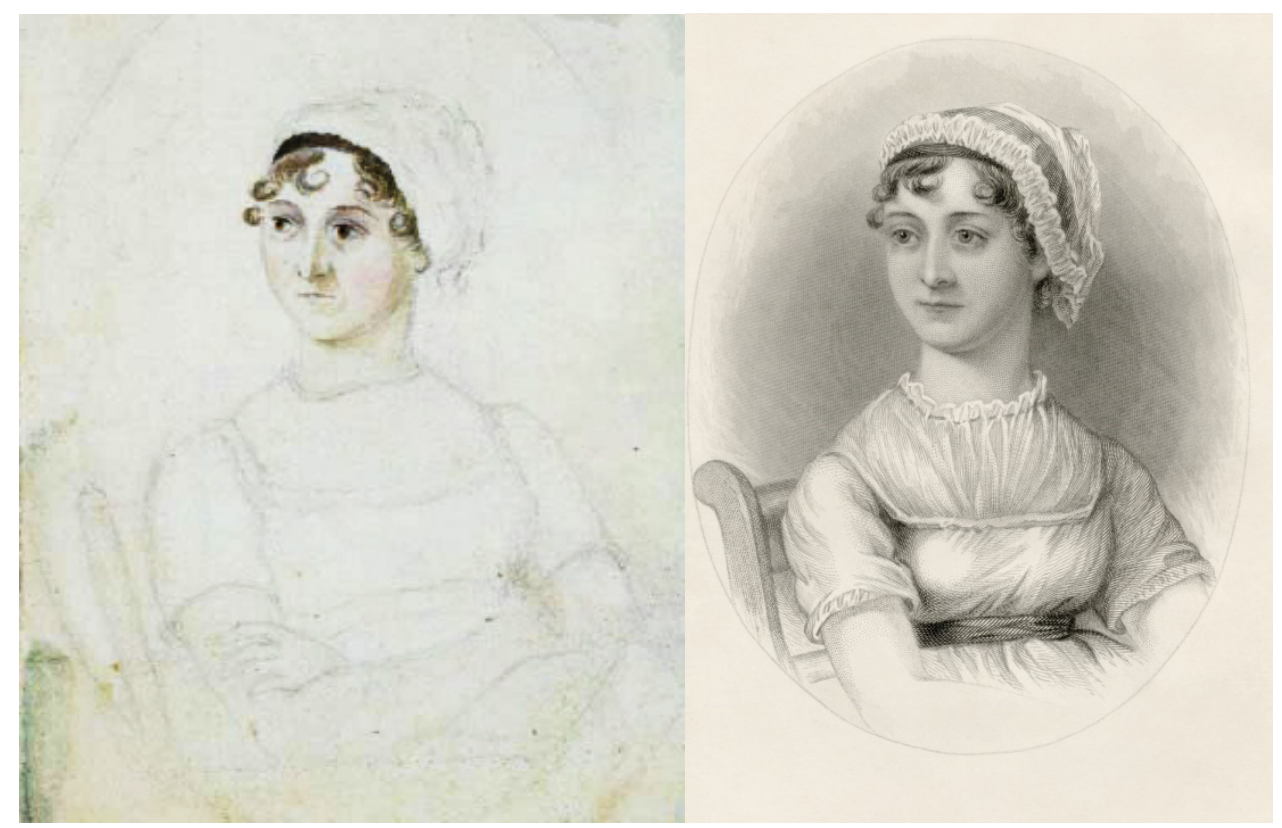

Fig. 3 Portrait of Jane Austen in watercolour and pencil by Cassandra Austen (c. 1810) [Public domain], via Wikimedia Commons
Andrews of Maidenhead based on an unfinished work by Cassandra Austen [Public domain], via Wikimedia Commons)

Fig. 4 Engraving of Jane Austen by William

Home Lizars from a watercolour by James 


\section{Photographing Celebrity Authorship}

[T] he use of the carte de visite, in making us familiar with the features of those who have made themselves famous, is indubitable. It seems as if we could not realize the nature of a man's sayings or doings unless read by the light of his countenance. (Wynter 1863, pp. 315-316)

Photographic technologies expanded picture identification and produced new interchanges between anonymity and celebrity. While contemporary scholars join Walter Benjamin's critique of mechanical reproduction (Easley 2013, p. 39; Blake 2008, p. 42), in 1863 Andrew Wynter cautions, 'It is a great mistake to suppose that the art of [photographic] portrait-taking has degenerated into a mere mechanical trade' (Wynter 1863, p. 308). Many Victorians saw photographs as portraits painted by the sun in interaction with chemicals, a product of nature and science rather than art, a process that intensified the immanence of portraiture. In 1843, Elizabeth Barrett Browning considered the daguerreotype to be 'the very sanctification of portraits', preferable to 'the noblest Artist's work ever produced', because it was a 'facsimile' of the body, 'the very shadow of the person lying there fixed for ever', and 'delicate beyond the work of the engraver' (Browning 1983, 2: pp. 357-358). Anne Thackeray found photographic portraits to be more revealing of another's identity than words: 'a photograph of your friend will to a certain point, tell you more about him in one minute than whole pages of elaborate description. You see him himself - the identity is there' (Thackeray 1876, p. 358).

When new technologies allowed photographs to be affordably mass-produced, photographic cartes de visite (small photographs, approximately 9 x $6 \mathrm{~cm}$, mounted on card) of celebrities and unknowns sold between 300 and 400 million annually, peaking in 1862 (Blodgett 1979, p. 67). ${ }^{5}$ In that year, American columnist Fanny Fern contrasts the sacred, private, intimate exchange of one-of-a kind portraits, whether 
painted or daguerreotype, to the promiscuity of mass-produced photographs publicly displayed:

There was a time when the presentation of one's 'likeness' meant something. It was a sacred thing, exchanged only between lovers or married people, kept carefully from unsympathizing eyes, gazed at in private as a treasure apart. But we have changed all that now. People like their faces to hang out at street doors, and in galleries, to lie on everybody's and anybody's table in albums, and to be hawked about promiscuously and vulgarly $[. .$.$] for the gaze of the curious. (Fern$ 1862, p. 12, original emphasis)

Like Brontë and Thackeray, Fern makes no rhetorical distinction between persons and their representations.

Cartes of male authors circulated more widely than those of women: a periodical journalist indicates that 'Literary men have a constant sale: Dickens, Thackeray, and Trollope, are bought for every album' ('Cartes de Visite', Once a Week 1862, p. 136); no female author is mentioned. Apart from their dowdy Queen, the public preferred female photographs of beauties, particularly princesses, actresses, and singers. In this context, popular sensation fiction writer Mary Elizabeth Braddon forged a bridge across two indices of value for this new mode of picture identification, just as author-aristocrats Byron, Scott, Blessington, and Morgan had done for engraved picture identification in the 1830s. Braddon had been an actress and was considered attractive; her carte de visite circulated widely from 1865 . One posted on the National Portrait Gallery website indicates that it did not bear the author's name in print, but rather a caption gesturing to older anonymous practices of crediting authors: 'Authoress of Lady Audley’s, Secret, Aurora Floyd \&c.'. The carte, however, bears her proper name as autograph; it appears to have been added by the 
author in heavy black ink. This was, however, not peculiar to women or authors; most cartes de visite did not bear printed names at all. Instead, they bore the names of the studios that produced them. The assumption was that the name was unnecessary; the face 'told' the name. One of the hallmarks of nineteenth-century authors who passed from celebrity to fame (in Arnold's sense) is that their cartes identify them to posterity without names, by contrast to the thousands of unidentified cartes of unknowns circulating today among collectors in antique shops, galleries, museums, and reprinted in books or posted on the World Wide Web.

By the end of the century, it was commonplace to picture identify women authors whether they were beautiful or not. In 1893, Helen C. Black published Notable Women Authors of the Day: Biographical Sketches with Portraits, collecting them together in a series published in Lady's Pictorial. Many were not particularly notable, even then; few were beautiful by standards of the day; all include autographs. As with Dickens's and Brontë's portrait signatures, many address the reader-viewer in the second person ('Very sincerely yours', 'Ever yours affectionately'), perhaps to offset third-person objectification and physiognomical judgment.

The picture identification of living women authors within the pages of their own fiction was pioneered in the last quarter of the century. In 1875, the daring Ouida (Marie Louise de la Ramée) sent a photograph of herself to be engraved for the frontispiece of the German edition of her novel, Signa (Moody 2013, p. 116). By the end of the century, portraits of authors were common in works of fiction regardless of gender. As with the withholding of the name early in the century, late in the century, withholding one's portrait in a quest for pictorial anonymity intensified the celebrity effect of subsequently providing one. For years, Marie Corelli (Mary Mackay) forbade publication of her photographs. Wanting to be identified by words produced 
by her body rather than images of her body produced by others, she substituted her autograph on title pages and imprinted her embossed initials on book covers (White 2013, pp. 205-207). When she finally authorized a photograph to be printed in The Treasure of Heaven (1906), it broke sales records, selling 100,000 copies on the first day. While this was undoubtedly a savvy business move, Corelli may have withheld her image for other reasons: she insisted that the photo be retouched to make her appear younger and more slender (White 2013, p. 212; see Pope 2009 for before and after images). Here, a female author renders her own picture identification pseudonymous and partial— quite literally so, as she orders parts of her body and facial lines to be removed.

Yet more often than not, photographic technologies produced a loss of control over one's images. In 1856, Dickens protested against 'the multiplication of my countenance in the Shop-Windows' (Dickens 1995: 8.245). With the advent of Kodak cameras, authors were constantly photographed by fans; while they could withhold their autographs, they could not elude photographic capture. Thomas Hardy and Ouida both expressed distaste for being 'kodaked'; Ouida wrote of '[t]he intolerable Kodak' and 'the intolerable interviewer' who jointly sought to picture identify her in the popular press (Green-Lewis 1996, p. 68; Ouida 1897, p. 187). With the development of photographic technologies, the general population was not only able to afford to be photographed, but also to take photographs, democratizing and dispersing celebrity picture identification.

\section{Moving Picture Identification}

The advent of moving pictures created other dynamics between anonymity and celebrity. Living authors appeared on screen in propria persona. The prologue to Masks and Faces (Ideal 1917), for example, depicts dramatists George Bernard Shaw, 
James Barrie, and Arthur Pinero discussing the beneficial exchanges of theatre and film (see Elliott 2003, pp. 115-116). In this and other films, moving images of authorial bodies are divorced from their names, as in cartes de visite, announced by film credits on separate title cards rather than below their images. Their moving bodies speak, but their uttered words are muted and represented as writing on title cards. These ruptures between pictures and names and the substitution of writing for speech opened up new intersemiotic exchanges between and within words and images, simultaneously building on and fracturing older modes of picture identification. The representation of muted speech as writing reinforces the notion that writing expresses the biographical author; it equally blurs distinctions drawn between the two by linguists and philosophers.

Early films representing dead authors also rework prior technologies of picture identification. The establishing shot for a 1922 British film of Vanity Fair, for example, represents Thackeray's face carved out in filmic close-up from a threequarter-length frontispiece portrait produced for an 1898 edition of his collected works. Still portraits in film conventionally signal dead or absent persons; the image presents the author as dead and absent not only in fact, by also contrast to the moving images of his fictional characters. His dead image simultaneously births and authorizes the film (its copyright is predicated on his biographical death), and the film is credited to other authors.

By contrast, the Edison company's 1915 film of Vanity Fair presents 'Thackeray' (played by Harold Hubert) as a living author writing the book and, implicitly, the film, which is bookended by scenes of 'Thackeray' starting to write the book and finishing it (see Elliott 2012a). In 'The Death of the Author' Barthes perceives 'Writing [to be] that neutral, composite, oblique space where our subject 
slips away, the negative where all identity is lost, starting with the very identity of the body writing' (p. 142). Barthes castrates the writing hand from both speech and body as 'a pure gesture of inscription' (1977a, p. 146). Edison's Vanity Fair (1915), however, restores the writing hand to the body and represents 'the very identity of the body writing'.

Unlike Edison's Thackeray, the actor playing the writing 'Dickens' in the film company Zenith's Old Scrooge (1913) remains uncredited. To credit the actor would attach two names to one picture, undermining both the author function and the authorial picture identification. Foucault considers that the author function is lost when an author is proven not to have written texts attributed to him; in literary film adaptation, however, the author name and function extend to works that the author is known not to have written.

Old Scrooge undertakes a redoubled exchange of anonymity and celebrity. As mentioned above, the actor playing Dickens is not credited. Seymour Hicks, on the other hand, who wrote the screenplay and took the role of Scrooge, is not credited as the film's writer. This enhances the author illusion performed by the actor playing Dickens and foregrounds Hicks' own celebrity as an actor. Moreover, far from differentiating the author from his characters, 'Dickens' becomes a character in the film, costumed and shot like his characters.

In the Nordisk film company's David Copperfield (1923), this equation of the author with the characters becomes didactic. Its penultimate scene depicts David celebrating the success of his first novel; the final sequence claims character name as authorial pseudonym:

Intertitle: Fifteen years later we find a famous author in the happiest period of his life. He calls himself--David Copperfield . . .

Long shot: David, Agnes, and three children seated in a garden 
Superimposed title: ... But his real name is ... CHARLES DICKENS ...

Medium close-up shot: a middle-aged uncredited actor as Charles Dickens

The picture identification, achieved by interplays and overlays between film words and images, reinscribes celebrity and anonymity through eponymity. However, the removal of the pseudonym and revelation of the 'real name' are undermined by the moving images that represent the 'real' Charles Dickens by an actor. The withheld name of the actor subverts the revelation of the 'real name' with a new anonymity. Since two named actors have already represented the child David (Buddy Martin) and the young man David (Gorm Smidd), the final shot presenting an uncredited, middleaged actor as Charles Dickens gives the audience a total of six actors and characters in search of an author. If the identical images and names of mass-produced picture identification seek to fix an individual identity, the picture identification of early cinema multiplies and fragments names and faces so that the author's identificatory indeterminacy arises from a surplus rather than an absence or lack of images and names. Increasingly, the public's quest to discover the identities of anonymous actors would create a new craze for picture identification (de Cordova 1990, p. 98) that would eclipse the interest in picture identifying literary authors.

Many critics find emptiness and nonexistence — anonymity — at the core of mass-produced picture identification (e.g., Easley 2011, p. 39). Structuralist theorists declare an essentialist opposition between words and images (Elliott 2005, pp. 1-2), and poststructuralist theorists proclaim the death of authors and a divorce between biographical and literary author names. However, as we have seen here, the picture identification of authors over the long nineteenth century actually forged a panoply of competing, conflicting, changing intersemiotic relations between the words and 
images that navigated passages from anonymity to celebrity to reveal the interdependence of all four.

\section{Notes}

${ }^{1}$ The People's Art Union was established in 1837 'for the advancement of the Fine Arts' (Morning Chronicle, 11 April 1837).

${ }^{2}$ In 1788, the editors of the Catalogue of Five Hundred Celebrated Authors of Great Britain, Now Living also assessed that 'The world is now better disposed to do justice to living merit' (1788, p. iv; see Ives 2012, p 1).

${ }^{3}$ Each entry begins on a new page 1 .

${ }^{4}$ Dickens only picture-identified himself within his fiction once: subsequently, he returned to convention, allowing frontispieces representing characters to face the title page.

${ }^{5}$ See Blodgett for the technical specifications of cartes de visite.

\section{Notes on contributor}

Kamilla Elliott is Professor of Literature and Media in the Department of English and Creative Writing at Lancaster University. Her principal teaching and research interests lie in relations between British literature of the long nineteenth century and other media. Author of Rethinking the Novel/Film Debate (Cambridge University Press, 2003) and Portraiture and British Gothic Fiction: The Rise of Picture Identification, 1764-1835 (Johns Hopkins University Press, 2012), she is currently working on sequels to both: Rethinking the Adaptation/Theorization Debate and British Literature and the Rise of Picture Identification, 1836-1918.

Professor Kamilla Elliott

English and Creative Writing

Lancaster University

Bailrigg, LANCS LA1 4YD

Office: County Main B211

k.elliott@lancaster.ac.uk

\section{References}


Anon, 1788. Catalogue of Five Hundred Celebrated Authors of Great Britain, Now Living. London: R. Faulder.

Anon, 1827. Sir Walter Scott, the Avowed Author of the Waverley Novels. The Mirror of Literature, Amusement, and Instruction, 9 (242), 3 March, 154-155.

Anon, 1834. Leslie's Portrait of Sir Walter Scott. In: A. A. Watts, ed., The Literary Souvenir. London: Longman, Reese, Orme, Brown, Green, \& Longman, 307.

Anon, 1858. Graphiology. The London Journal: and Weekly Record of Literature, Science, and Art 28 (706), 28 August, 45.

Anon, 1845. The People's Art Union: The Historic Gallery of Portraits \& Paintings, with Brief Memoirs of the Most Celebrated Men of Every Age and Country, vol. I. London: Willoughby \& Co.

Anon, 1862. Cartes de Visite. Once a Week, 6 (135), 25 January, 134-137.

Anon, 1862. Merry Christmas. London Society, 2, 5.

Anon, 1873. The Vanity Fair Album. Saturday Review, 22 March, 384-385.

Anon, 1881. The Portrait of George Eliot. The Century Illustrated Monthly Magazine, 23, November, 47-48.

Arnold, M., 1863. The Bishop and the Philosopher. Macmillan's Magazine, 7 (39), January, 241-256.

Banting, P. 1995. Body, Inc. Winnipeg: Turnstone.

Bantock, L., 1913. Old Scrooge. London: Zenith Films.

Barthes, R., 1977. The Death of the Author. In: Image-Music-Text, trans. Stephen Heath. New York: Hill \& Wang, 142-148.

Bassett, T., 2012. 'A Characteristic Product of the Present Era': Gender and Celebrity in Helen C. Black's Notable Women Authors of the Day (1893). In: A. R. Hawkins and M. Ives, eds. Women Writers and the Artifacts of Celebrity in the Long Nineteenth Century. Farnham: Ashgate, 151-168.

Black, H. C., 1893. Notable Women Authors of the Day: Biographical Sketches with Portraits. Glasgow: D. Bryce \& Son.

Blake, D. H., 2008. Walt Whitman and the American Culture of Celebrity. New Haven: Yale University Press.

Blodgett, R. E., 1979. Photographs: A Collector's Guide. New York: Ballantine.

Boone, J. A. and Vickers, N. J., 2011. Celebrity Rites. PMLA, 126 (4), 900-911.

Brabin, C. J. and Nowland, E., 1915. Vanity Fair. New York: Edison. 
Braudy, L., 1986. The Frenzy of Renown: Fame and Its History. Oxford: Oxford University Press.

Brontë, C., 2004. Letter to George M. Smith, 26 Feb. 1853. In: M. Smith, ed. The Letters of Charlotte Brontë, 3 vols. Oxford: Clarendon Press, vol. 3, 128-29. Browning, E. B., 1983. The Letters of Elizabeth Barrett Browning to Mary Russell Mitford, 1836-1854. M. B. Raymond and M. R. Sullivan, eds., 3 vols. Waco, TX: Armstrong Browning Library of Baylor University.

Charlotte Brontë by George Richmond, chalk, 1850. Available at http://www.npg.org.uk/collections/search/portrait/mw00798/CharlotteBront?LinkID $=$ mp00572\&search $=$ sas \&sText $=$ charlotte + bronte $\& O C o n l y=$ true \&role $=$ sit $\& \mathrm{rNo}=1$ [Accessed 25 July $].$

Chorley, H. F., 1838. The Authors of England: A Series of Medallion Portraits of Modern Literary Characters, Engraved from the Works of British Artists, by Achille Collas, with Illustrative Notices by H. F. Chorley. London: Charles Tilt.

Cohen, J. R., 1980. Charles Dickens and His Original Illustrators. Columbus: Ohio State University Press.

Corelli, M., 1906. The Treasure of Heaven: A Romance of Riches. London: A. Constable

De Cordova, R., 2001. Picture Personalities: The Emergence of the Star System in America., Urbana: University of Illinois Press.

De la Manch, D. R. de L. S., 1832. Character of Spirit, or Mystery, of the Art of Publishing Oneself, or Anything. The Diamond Magazine, 8, 105-106.

Dickens, C., 1995. The Letters of Charles Dickens. In: G. Storey and K. Tillotson, eds. Oxford: Clarendon, vol. 8, 245.

Easley, A., 2011. Literary Celebrity, Gender, and Victorian Authorship, 1850-1914. Newark: University of Delaware Press.

Eckroth, S., 2012. Celebrity and Anonymity in the Monthly Review's Notices of Nineteenth-Century Novels. In: A. R. Hawkins and M. Ives, eds. Women Writers and the Artifacts of Celebrity in the Long Nineteenth Century. Farnham: Ashgate, 13-32.

Elliott, K., 2003. Rethinking the Novel/Film Debate. Cambridge: Cambridge University Press. 
—, 2005. Novels, Films, and the Word/Image Wars. In: R. Stam and A. Raengo, eds.

A Companion to Film and Literature. Oxford: Blackwell, 2004, 1-22.

—, 2012a. Screened Writers. In: D. Cartmell, ed. The Blackwell Companion to

Literature, Film, and Adaptation. Oxford: Blackwell, 179-197.

-, 2012b. Portraiture and British Gothic Fiction: The Rise of Picture Identification, 1764-1835. Baltimore: Johns Hopkins University Press.

Fern, F., 1862. Then and Now. The American Scrap Book and Magazine of United States Literature, vol. 2, 12.

Foucault, M., 1984. What is an author? In: P. Rabinow, ed. The Foucault Reader. New York: Pantheon, 101-120.

Gaskell, E.C., 1857. The Life of Charlotte Brontë. London: Smith, Elder, and Co.

George Eliot, carte de visite, by London Stereoscopic \& Photographic Company albumen print. Available at http://www.npg.org.uk/collections/search/portrait/mw189744/George-EliotMary-Ann-Cross-neEvans? LinkID $=$ mp01124\&search $=$ sas $\&$ sText $=$ george + eliot $\&$ role $=$ sit $\& \mathrm{rNo}=8$ [Accessed 25 July 2016].

Gould, M., 2011. The Theatre. In: S. Ledger and H. Furneaux, eds. Charles Dickens in Context. Cambridge: Cambridge University Press, 125-132.

Granger, J., 1769. A Biographical History of England, 5th edn., 6 vols. London: T. Davies.

Green-Lewis, J., 1996. Framing the Victorians: Photography and the Culture of Realism. Ithaca: Cornell University Press.

Greenfield, J. R., 1996. British Short Fiction Writers, 1800-1880. Detroit: Gale Research.

Griffin, R. J., 2006. Anonymous. In: D. S. Kastan, ed. The Oxford Encyclopedia of British Literature. Oxford: Blackwell, 48-51.

Hadjiafxendi, K., 2013. Negotiating Fame: Mid-Victorian Women Writers and the Romantic Myth of the Gentlemanly Reviewer. In: K. Hadjiafxendi and P. Zakreski, eds. Crafting the Woman Professional in the Long Nineteenth Century: Artistry and Industry in Britain. Farnham: Ashgate, 187-205.

Hawkins, A. R., 2012. The Portrait, the Beauty, and the Book: Celebrity and the Countess of Blessington. In: A. R. Hawkins and M. Ives, eds. Women Writers 
and the Artifacts of Celebrity in the Long Nineteenth Century. Farnham: Ashgate, 49-78.

Hayden, J. O., 1970. Introduction. In: J. O. Hayden, ed. Walter Scott: The Critical Heritage. London: Routledge, 1-24.

Ives, M. C., 2012. Introduction. In: A. R. Hawkins and M. C. Ives, eds. Women Writers and the Artifacts of Celebrity in the Long Nineteenth Century. Farnham: Ashgate, 1-12.

Jerdan, W., 1830-34. National Portrait Gallery of Eminent Personages of the Nineteenth Century; with Memoirs, 5 vols. London: Fisher, Son, \& Jackson.

Kirkham, M., 2005. Portraits. In: J. Todd, ed. Jane Austen in Context. Cambridge: Cambridge University Press, 68-82.

Lodge, E., 1835. Portraits of Illustrious Personages of Great Britain, with Biographical and Historical Memoirs of their Lives and Actions. London: Harding and Lepard, vol. 1.

Moody, N., 2013. Defending Female Genius: The Unlikely Cultural Alignment of Marie Corelli and Ouida. In: A. King and J. Jordan, eds. Ouida and Victorian Popular Culture. Farnham: Ashgate, 108-128.

Ouida, 1897. An Altruist and Four Essays. Leipzig: Tauchnitz.

Patten, R. L., 2001. From Sketches to Nickleby. In: J. O. Jordan, ed. The Cambridge Companion to Charles Dickens. Cambridge: Cambridge University Press, 1633.

Paul, F., 1917. Masks and Faces. London: Ideal Film Company.

Pope, C., 2009. The Mysterious Marie Corelli: Queen of Bestsellers. Notes from a Victorianist and Small Publisher, 12 May. Available from: http://blog.catherinepope.co.uk/2009/05/the-mysterious-marie-corelli-queenof-bestsellers/. Accessed 12 June 2015.

Payne, G. A., 1900. Mrs. Gaskell and Knutsford. Manchester: Clarkson \& Griffiths. Rowden, W. C., 1922. Vanity Fair, Tense Moments with Great Authors film series, London: Master Films.

Sandberg, A. W., 1922. David Copperfield. Copenhagen: Nordisk Film.

Schickel, R., 1985. Intimate Strangers: The Culture of Celebrity in America. Chicago: Gideon Productions, Inc.

Smith, G. M., 1900. Charlotte Brontë. Cornhill Magazine, 9, December, 778-795. 
Smith, S. M., 1999. American Archives: Gender, Race, and Class in Visual Culture. Princeton: Princeton University Press.

Stott, A., 2003. Hannah More: The First Victorian. Oxford: Oxford University Press.

Thackeray, A., 1876. Toilers and Spinsters and Other Essays. London: Smith, Elder, $\&$ Co.

Turner, G., 2004. Understanding Celebrity. London: Sage.

White, L., 2012. Commodifying the Self: Portraits of the Artist in the Novels of Marie Corelli. In: A. R. Hawkins and M. Ives, eds. Women Writers and the Artifacts of Celebrity in the Long Nineteenth Century. Farnham: Ashgate, 205-218.

Wynter, A., 1863. Photographic Portraiture. Subtle Brains and Lissom Fingers, and Other Papers. London: Robert Hardwicke, 297-317.

Zakreski, P., 2006. Representing Female Artistic Labour, 1848-1890: Refining Work for the Middle-Class Woman. Farnham: Ashgate. 